\section{Diversos aspectos didácticos de la clase \\ de Geografía General de México para \\ alumnos extranjeros de nivel 1 y 2 de \\ español}

México tiene una geografía envidiable, por su latitud y por la diversidad de recursos naturales.

Los recursos naturales que México posee pueden engl obarse en el campo de estudio de la Geología, la Geomorfología, el Volcanismo, la Sismicidad, Ios climas, la vegetación, la fauna y el turismo, para su reconocimiento y su localización.

Para la enseñanza de todos estos aspectos geográficos, a los al umnos extranjeros, es necesario aplicar técnicas o métodos adecuados que logren un buen aprendizaje de los diversos cursos de Geografía que se imparten en el Centro de Enseñanza para Extranjeros (CEPE).

La enseñanza de la Geografía de México a los al umnos extranjeros es muy importante, ya que les permite ubicase mejor en el país y conocer los diversos paisajes, las diferentes regiones culturales, así como también los recursos natural es existentes en todo el país.

Durante el tiempo que me he dedicado a la enseñanza de la Geografía de mi país y del continente americano para los al umnos extranjeros, -los cuales se ven limitados por el idioma-, siempre he tratado de actualizar periódicamente mi material didáctico y presentar material más funcional para su estudio. Por ello, en este trabajo explico el uso de los diversos material es didácticos para la enseñanza y el conocimiento de la Geografía de México y de América.

El primer tipo de material que utilizo es el escrito, el cual es elaborado de manera clara y sencilla para evitar confusión de contenido y significados, y se procura que sea entregado a los al umnos con anticipación para que lo lean y comprendan mejor los temas vistos en clase, asimismo, en cada exposición se entrega un glosario de términos geográficos para su mejor compresión; las notas de clase van siempre acompañadas de mapas relacionados
Ma. Eugenia Villagómez Hernández CEPE-UNAM 
con cada tema. Por ejemplo el tema titulado Unidades orogénicas del México. Donde se estudia el origen de los movimientos tectónicos u orogénicos que formaron plagamientos, fracturas y fallas dando lugar a la formación de los sistemas montañosos, la formación de mesetas y zonas planas y bajas.

Otro tipo de material didáctico que se usa en cada clase son las presentaciones en Power Point, en donde con base en una investigación bibliografía, hemerográfica o en la red, se buscan las imágenes de los contenidostemáticos del programa, se digitalizan y presentan al alumno en clase.

Otra herramienta útil en la enseñanza de la Geografía a los al umnos extranjeros es la exhibición de películas con contenido geográfico o que reflejan el entorno político, económico, social y cultural que vive México.

El uso de estos materiales propicia en el alumno el conocimiento y aprendizaje de más pal abras en español y en el entorno geográfico y social del país.

Para reforzar al aprendizaje del español y los temas de Geografía, al al umno extranjero se le pide que consulte y revise los periódicos que se publican en la ciudad y que elijan un artículo, lo recorten, lo lean y que elaboren un breve resumen de la nota sel eccionada y un comentario.

Se puede también agregar al estudio de los temas geográficos, el uso de relatos o leyendas de las diversas partes del país, para ello, se le entrega a cada al umno una copia de un relato, el cual lo leerán y con ayuda del profesor se interpretara su si gnificado, esta actividad resulta muy divertida y enriquecedora para los alumnos y con conllevaa que ell os también narren historias o relatos de sus países.

Los mapas son otro recurso didáctico muy importante para el desarrollo de los temas de clase, con ellos el alumno ubica mejor los aspectos que estudia, y asimismo, aprende a interpretar un mapa de tipo turístico, el cual lo puede ayudar en las visitas culturales que realiza en la ciudad o en el país.

También en la enseñanza de la Geografía en el CEPE, se apoya con la real ización de visitas guiadas a lugares de interés geográfico como el museo de Geología, el J ardín botánico, las áreas de cultivos hidropónicos, visita al museo Universum para observar exposiciones de flora y fauna de México. 